\title{
Mesenchymal Stem Cells in Bone Tissue Regeneration and Application to Bone Healing
}

\author{
Michal Crha ${ }^{1}$, Alois Nečas ${ }^{1}$, Robert Srnec ${ }^{1}$, Jan Janovec ${ }^{1}$, Ladislav Stehlík ${ }^{1}$, Petr Raušer ${ }^{1}$, \\ Lucie Urbanová ${ }^{1}$, Ladislav Plánka², Josef Jančář ${ }^{3}$, Evžen Amler ${ }^{4}$ \\ ${ }^{1}$ Department of Surgery and Orthopaedics, Small Animal Clinic, Faculty of Veterinary Medicine, \\ University of Veterinary and Pharmaceutical Sciences Brno, Czech Republic \\ ${ }^{2}$ Department of Pediatric Surgery, Orthopaedics and Traumatology, Faculty Hospital Brno, Czech Republic \\ ${ }^{3}$ Institute of Materials Chemistry, Brno University of Technology, Czech Republic \\ ${ }^{4}$ Laboratory of Tissue Engineering, Institute of Experimental Medicine, Academy of Sciences \\ of the Czech Republic, Prague, Czech Republic
}

Received May 18, 2009

Accepted September 8, 2009

\begin{abstract}
This synoptic study gives a concise overview of current knowledge of bone healing, the role of mesenchymal stem cells in bone tissue regeneration and contemporary possibilities of supporting regeneration of damaged bone. Attention of research concerning the healing of fractures with extensive loss of bone tissue following trauma, the treatment of belatedly healing or non-healing fractures or the healing of segmental bone defects following tumour resection, is focused on development of three-dimensional scaffolds planted with mesenchymal stem cells that might be used for reconstruction of such large bone lesions. Presented are possibilities of transplantation of mesenchymal stem cells combined with biomaterials into bone defects, including the results of our own experimental studies dealing with the use of stem cells in the treatment of damaged tissues of the musculoskeletal system in animal models.
\end{abstract}

Tissue engineering, biomaterials, scaffold, segmental bone lesion, fracture healing, growth factors, review

Contemporary research currently focuses on the use of mesenchymal stem cells (MSCs) for the purpose of regeneration of damaged tissues of the musculoskeletal system, such as the cartilage, bone, ligaments, muscles and tendons (Ahn et al. 2004; Arinzeh 2005; Arthur et al. 2009; Award et al. 2003; Chen et al. 2003; Dressler et al. 2005; Gál et al. 2007; Hoemann et al. 2005; Lee and Hui 2006; Plánka et al. 2007, Shirly et al. 2005; Kraus and Kirker-Head 2006; Nečas et al. 2008; Noel et al. 2002; Waese et al. 2008; Zaidi and Nixon 2007). Bone tissue is capable of regeneration, yet the natural bone healing process is in some cases insufficient. For example, excessive loss of bone due to trauma or tumour resection, non-healing fractures, metabolic diseases, arthrodesis, vertebral fusion, insufficient healing capacity due to systemic, local disease or age etc., present cases where bone regeneration using transplantation of MSCs alone or combined with biomaterials may bring the required result of successful healing of the particular bone defect (Cancedda et al. 2003, Caplan 2005; Drosse et al. 2008; Jančář et al. 2007; Kraus and Kirker-Head 2006; Nečas et al. 2008; Salgado et al. 2006; Slater et al. 2008; Viateau et al. 2007). The aim of this work was to give a concise overview of existing knowledge from experimental studies on regeneration of bone tissue using methods of tissue engineering with the application of MSCs transplantation; and concurrently, to inform on the results of our own research studies in relation to MSCs transplantation into the tissues of the musculoskeletal system in animal models (miniature pig, New Zealand white rabbit).

Address for correspondence:

MVDr. Michal Crha, Ph.D.

Department of Surgery and Orthopaedics

Small Animal Clinic

Faculty of Veterinary Medicine

University of Veterinary and Pharmaceutical Sciences Brno

Palackeho 1-3, 61242 Brno, Czech Republic

Phone: +420 541562362

E-mail: crham@vfu.cz

http://www.vfu.cz/acta-vet/actavet.htm 


\section{Role of MSCs in bone tissue regeneration}

When bone integrity is damaged (e.g. after fracture), under normal circumstances MSCs play an important role in its healing. MSCs are multipotent cells of mesodermal origin capable of differentiating into osteoblasts, chondrocytes, adipocytes, tenocytes and myoblasts (Heino and Hentunen 2008; Jaswal et al. 1997; Krampera et al. 2006; Marie and Fromigue 2006; Pittenger et al. 1999; Smith 2006). These cells are identified as marrow stromal cells (supporting the cells of bone marrow), because they are relatively abundant in the bone marrow which is their suitable source. Apart from bone marrow, they are found in the endosteum of the trabecular bone, and the periosteum (Stocum 2001). A limited source of MSCs is the fat tissue, funicle blood, muscle and synovial membrane (Yoo and Johnstone 1998; Bruder et al. 1997). MSCs are found in small quantities in peripheral blood and other tissues (Kuznetsov et al. 2001). They have been isolated e.g. from the liver, brain and pancreas (Porada et al. 2006).

MSCs of the bone marrow and endosteum originate from the periosteum. During foetal development the calcified cartilage of endochondral bone is gradually reconstructed and vascularised, MSCs are transferred from the periosteum to the marrow cavity where MSCs are further differentiated into osteoblasts substituting bone cartilage, fibroblasts and adipocytes that form the supporting tissue of the bone marrow in formation. Concurrently, part of the MSC population in bone marrow remains unchanged and forms the source of undifferentiated stem cells (Stocum 2001). Bone regeneration is analogous to embryonic development of the skeleton. It is provided by a sum of cellular, humoral and mechanical factors involved in the new formation of bone in which MSCs play an important role. At the site of the fracture line the bone is damaged, which is accompanied by bleeding. Cytokines released from the damaged matrix of the bone and from degranulated thrombocytes form a mix of biologically active proteins, some of which affect MSCs chemotactically. MSCs from the periosteum and bone marrow are transferred to the location of bone damage where they continue to multiply and differentiate into osteoblastic, chondroblastic and fibroblastic lines of cells (Oe et al. 2007) responsible for the production of bone matter and cartilage that form a callus at the fracture site (Einhorn 1998; Carter et al. 1998). Recently published studies show that during bone injury, MSCs are flowed from bone marrow to peripheral blood. Through peripheral blood the originally distant MSCs are transferred to the site of bone injury where they reinforce the healing potential of local MSCs (Devine at al. 2002; Shirley et al. 2005). Bone morphogenic proteins (BMPs) play an important role during prenatal development and bone regeneration (Reddi 2000). They carry out the task of cytokines that fundamentally influence MSCs, as they can modify their differentiation (Edgar et al. 2007). Osteogenesis is the result of mutual interaction of individual types of BMPs, when e.g. BMP-2, -4 , and -7 are responsible mainly for the induction of osteogenesis, whereas BMP-12, -13 , and -14 are connected with cartilage formation (Reddi 2001; Li and Wozney 2001; Carter 2003).

Methods of MSCs isolation are based on their ability to divide and adhere to the substrate or surface of the cultivation container (Caplan 1991; Stocum 2001). During cultivation and the passaging of cells obtained by bone marrow aspiration, MSCs may be separated by a change of the cultivation medium from the cells that do not possess the ability of adhesion and move freely in the cultivation solution (e.g. the line of haematopoietic stem cells, HSCs) (Stocum 2001). The results of experimental studies point out that during cultivation in vitro, MSCs may be directed toward transformation into lines of cells that are capable of producing bone matter by being exposed to the effects of a number of substances, such as the transforming growth factor (TGF), vascular endothelial growth factor (VEGF), insulin-like growth factor (IGF), dexamethasone or glycerol phosphate, vitamin D and bone morphogenic protein 2 (BMP-2) (Pluhar 2004; Anitua et al. 2004a; 
Carter 2003; Anitua et al. 2004b; Marx 2004, Pittenger et al. 1999, Prockop 1997). Experimental studies report other properties of MSCs, such as the ability to maintain the possibility of division after cryopreservation (Bruder 1997) or their immunotolerance. Some studies suggest that MSCs lack certain receptors on their surface which allows them to escape the T-cell component of immunity (Pittenger et al. 1999; Devine 2002). Other studies even point out immunosuppressive properties of MSCs after their transplantation (Devine et al. 2001; Bartholomew et al. 2002; Porada et al. 2006). It is assumed that due to these immunological properties, allogeneic MSCs might be used in transplantations as effectively as autogenous MSCs (Arinzeh et al. 2003; Kraus a Kirker-Head 2006). A possibility has even been described of xenogeneic transplantation of MSCs for the purpose of bone tissue regeneration in rabbits (Bruder et al. 1998b).

\section{Contemporary strategies of supporting bone defect healing}

Regeneration of damaged bone is related to several fundamental processes: osteogenesis, osteoinduction, osteoconduction and osteopromotion. Efforts are made to achieve the most effective way of regeneration possible, using the optimum combination of these four processes with the application of MSC implantation (Bruder and Fox 1999; Nečas et al. 2008, Viateau et al. 2007; Kirker-Head et al. 2007). The best example of the use of the osteogenic potential of transplanted cells is the autogenous spongeous bone graft (Kraus and Kirker-Head 2006). The collection location in dogs and cats is crista iliaca or tumerculum majus humeri, in horses it is sternum and alla ossis ilii (Johnson 2007). The disadvantage of graft collection is the necessity of preparing another operation field, which increases the material cost and lengthens the surgery time. A relative disadvantage is also the insufficient yield of a graft in small or old individuals. In humans, graft collection is moreover associated with subsequent pain at the graft collection location and higher morbidity (Beirne et al. 1996; Silber et al. 2003; Joshi and Kostakis 2004). Autogenous spongeous bone graft is considered the "golden standard" among tissue transplants supporting bone regeneration, but not always all aspects of the application of this graft are ideal for clinical practice. Attention of contemporary research is therefore directed to the finding of an optimum substitute for the standard bone grafts used. Promising results have been yielded by the application of BMPs combined with materials showing osetoconductive properties, such as deproteinised bone, some forms of demineralised bone matrix (DBM), synthetic collagene, hydroxyapatite, tricalcium phosphate, hydrogel based on hyaluronic acid and some synthetic polymers based on polyglycolic acid or polylactate (Cook et al. 1994; Gao et al. 1996; Boyan et al. 1999; Yamamoto et al. 1998; Horisaka et al. 1991; Hotz and Herr 1994). Commercial application of DNA recombinant technology allowed the synthesis of recombinant human bone morphogenic proteins (rh BMPs) using bacteria (e.g. Escherichia coli) (Vallejo et al. 2002). Production of the BMP has thus been substantially speeded up and facilitated, which contributed to its wider application in clinical practice. At present, rh BMP-2 (Genetics Institute, Boston, Massachusetts, USA) and rh BMP-7 Creative BioMolecules, Hopkinton, Massachusetts, USA) are commercially available on the U.S. market. Clinical application of rh BMPs has been described in humans in orthopaedic interventions (vertebral fusion, long bone defect healing, nonhealing fractures), in craniomaxillofacial surgery, and dentistry (Johnson and Urist 1998; Boyne 2001, Friedlaender et al. 2001; Burkus et al. 2002). The application of BMPs has yielded positive results in supporting bone regeneration, yet their exclusively osteoinductive property presents a certain strategic limitation. New bone formation is dependent on MSCs present at the location of bone damage that represent the source of osteogenic lines of cells capable of forming bone matter. In this sense, the strategy of using the osteogenic potential of MSCs transplanted into the bone defect appears promising. The subject of intensive research in the field of tissue engineering is the application of 
MSCs in combination with suitable scaffolds in order to achieve bone tissue regeneration. This would be a contribution for clinical practice in patients with extensive bone defects (tumour resection, traumatic injuries with bone loss, complicated fractures) or in cases of decreased healing ability of bone tissue (older age, osteoporosis) or genetic diseases of the skeleton (osteogenesis imperfecta) (Barry et al. 2001).

\section{Strategies of transplantation of MSCs in combination with biomaterials}

The primary aim of tissue engineering is the finding of suitable material biocompatible with bone tissue. For this purpose a number of osteoinductive carriers have been tested based on synthetic polymers, DBM, hydrogel, titanic fibres, natural coral and synthetic bioceramics based on hydroxyapatite and tricalcium phosphate (Bucholz et al. 1987; El-Ghannam 2005; Hotz and Herr 1994; Ishaug et al. 1997; Fleming et al. 2000; Hutmacher 2000; Oest et al. 2007; Srouji and Livne 2005; Wolff at al. 1994).

Synthetic materials based on hydroxyapatite and tricalcium phosphate show good ability of incorporation into bone tissue, which is due to their biocompatibility, degradability and porous structure allowing their intergrowth through newly formed bone (Bruder et al. 1998a; Marcacci et al. 1999). Their "merely" osteoinductive property, however, is insufficient for the healing of extensive bone defects (Bruder at al. 1998a). In contrast, synthetic polymers have lower ability of osetointegration compared to bioceramics, and their degradation is connected with stronger tissue reaction (Fleming 2000; Oest et al. 2007).

Attention of contemporary research is also focused on the development of threedimensional (3D) scaffolds planted with MSCs that might be used for the reconstruction of extensive bone defects. This strategy combines the osteogenic potential of MSCs with osteoconductive abilities of the scaffolds (Nečas et al. 2008; Viateau et al. 2007; Is hauga et al. 1997; Fleming et al. 2000; Kraus and Kirker-Head 2006; Kadiyala et al. 1997; Jančář et al. 2007), supplemented in some cases also with the osteopromotive component (Neuttelman et al. 2006; Kim et al. 2007; Kirker-Head et al. 2007; Rosenbaum et al. 2008). In experimental studies dealing with the reconstruction of large bone defects using 3D scaffolds planted with MSCs, the model animal used was the rat (Kadiyala et al. 1997; Bruder et al. 1998a; Srouji and Livne 2005), rabbit (Kirker-Head et al. 2007), dog (Kraus et al. 1999; Kraus and Kirker-Head 2006) and sheep (Marcacci et al. 1999; Viateau et al. 2007). In several studies, bioceramics was used as the carrier (Kraus et al. 1999; Kraus and Kirker-Head 2006). Recently published studies focus on the development and transplantation of a scaffold based on fibroin (protein derived from the silk produced by the silkworm moth caterpillar) combined with MSCs or BMPs (KirkerHead 2007; Meinel et al. 2006), or a bioactive scaffold composed of collagen and peptide derived from osteopontin (Lee at al. 2007).

In vivo experiments on animal models yield promising results. The experimental work of Kadiyala et al. (1997) points out that transplantation of allogeneic MSCs on a hydroxyapatite/tricalcium phosphate scaffold brought about faster healing of diaphyseal femoral defects in rats than the application of BMPs with a similar scaffold. Similar results are confirmed in other studies conducted on large animal models (Kirker-Head 2006; Viateau et al. 2007).

At present, we conduct in vivo studies at our department on the transplantation of MSCs combined with mechanically resistant, biocompatible resorbable scaffolds into segmental femoral defects in miniature pigs. For fixation of these segmental defects we use LCP plates (Locking Compression Plate, Synthes) in combination with lock screws (Plate VIII, Fig. 1). The healing process is continuously evaluated using radiological examination (Plate IX, Fig. 2) and computed tomography (Plate X, Fig. 3) as well as on the basis of performed mechanical tests of the firmness of operated femurs and histological examination 
of defect locations. Preliminary results of this study with regard to better bone defect healing appear promising. Verification of the regenerative potential of transplanted MSCs under conditions in vivo on animal models is the first step before the presumed therapeutic application of MSCs in clinical practice. For the future, the use of the osteogenic potential of MSCs in combination with biomaterials is considered in the healing of bone lesions in humans and animals, which could substitute existing methods of bone regeneration that are in some cases insufficient. Owing to the possibility of long-term storage of MSCs and the promising results of experimental studies on allogeneic transplantation of these cells, it is possible even to consider the use of tissue banks that might operatively provide MSC cultures for clinical purposes. It will be necessary, however, to search for answers to a number of other questions related to supporting the healing of damaged bone tissue using the transplantation of stem cells combined with biomaterials.

\section{Mezenchymové kmenové buňky v regeneraci kostní tkáně a jejich využití při hojení kostních defektů}

V této souhrnné práci je podán stručný přehled aktuálních poznatků o hojení kosti, roli mezenchymových kmenových buněk v regeneraci kostní tkáně a současných možnostech podpory regenerace porušené kosti. Pozornost výzkumu týkajícího se hojení zlomenin s velkou ztrátou kostní tkáně po traumatu, léčby opožděně se hojících či nehojících se zlomenin, př́ipadně hojení segmentálních kostních defektů po resekcích tumorů se soustředí na vývoj trojrozměrných skafoldů osazených mezenchymovými kmenovými buňkami, které by bylo možné využít k rekonstrukci těchto rozsáhlých kostních lézí. Uvedeny jsou proto možnosti transplantace mezenchymových kmenových buněk v kombinaci s biomateriály do defektů kostí, včetně výsledků vlastních experimentálních studií zabývajících se využitím kmenových buněk v léčbě poškozených tkání muskuloskeletálního systému u zvíŕecích modelů.

\section{Acknowledgments}

The study was supported by the Ministry of Education, Youth and Sports of the Czech Republic - project NPV II 2B06130, by the Grant Agency of the Academy of Sciences No. IAA500390702, by the IGA VFU Brno project No. 251/2009/FVL, and project IGA VFU Brno No. 259/2009/FVL.

\section{References}

Ahn JI, Canale TS, Butler SD, Hasty KA 2004: Stem cell repair of physeal cartilage. J Orthop Res 22: 1215-1221

Anitua E, Andia I, Ardaza B 2004a: Autologous platelets as a source of proteins for healing and tissue regeneration. Tromb Haemost 91: 4-15

Anitua E, Andia I, Sanchez M, Azofra J, Del Mar Zalduendo M, De La Fuente M, Nurden P, Nurden A 2004b: Autologous preparations rich in growth factors promote proliferation and induce VEGF and HGF production by human tendon cells in culutre. J Orthop Res 23: 281-286

Arinzeh TL 2005: Mesenchymal stem cells for bone repair: preclinical studies and potential orthopedic applications. Foot Ankle Clin 10: 651-665

Arinzeh TL, Peter SJ, Archambault MP, van den Bos C, Gordon S, Kraus K, Smith A, Kadiyala S 2003: Allogenic mesenchymal stem cells regenerate bone in a critical-sized canine segmental defect. J Bone Jt Surg Am 85: 1927- 1935

Arthur A, Zannettino A, Gronthos S 2009: The therapeutic applications of multipotential mesenchymal/stromal stem cells in skeletal tissue repair. J Cell Physiol 218: 237-245

Award H, Boivin GP, Dressler MR, Smith FN, Young RG, Butler DL 2003: Repair of patellar tendon injuries using a cell-collagen composite. J Orthop Res 21: 420-431

Barry F, Bonton RE, Liu B, Murphy JM 2001: Chondrogenic differentiation of mesenchymal stem cells from bone marrow: differentiation-dependent gene expression of matrix components. Exp Cell Res 268: 189-200

Bartholomew A, Sturgeon C, Siatskas M, Ferrer K, McIntosh K, Patil S, Hardy W, Devine S, Ucker D, Deans R, Moseley A, Hoffman R 2002: Mesenchymal stem cells suppress lymphocyte proliferation in vitro and prolong skin graft survival in vivo. Exp Hematol 30: 42-48

Beirne JC, Barry HJ, Brady FA, Morris VB 1996: Donor site morbidity of the anterior iliac crest following cancellous bone harvest. Int J Oral Maxillofac Surg 25: 268-271 
Boyan BD, Lohmann CH, Somers A, Niederauer GG, Wozney JM, Dean DD, Carnes Jr, Schwartz Z 1999: Potential of porous poly-D,L-lactide-co-glycolide particles as a carrier for recombinant human bone morphogenetic protein-2 during osteoinduction in vivo. J Biomed Mater Res 46: 51-59

Boyne PJ 2001: Application of bone morphogenetic proteins in the treatment of clinical oral and maxillofacial osseous defects. J Bone Joint Surg Am 83:146-150

Bruder SP, Fox BS 1999: Tissue engineering of bone. Cell based strategie. Clin Orthop 367: 68-83

Bruder SP, Jaiswal N, Haynesworth SE 1997: Growth kinitics, self-renewal, and the osteogenic potential of purified human mesenchymal stem cells during extensive subcultivation and following cryopreservation. J Cell Biochm 64: 278-294

Bruder SP, Jaswald N, Ricalton NS, Mosca JD, Kraus KH, Kadiyala S 1998a: Mesenchymal stem cells in osteobiology and applied bone regeneration. Clin Orthop Relat Res 355: 247-256

Bruder SP, Kurth AA, Shea M, Hayes WC, Jaiswal N, Kadiyala S 1998b: Bone regenaration by implantation of purified, culture-expanded human mesenchymal stem cells. J Orthop Res 16: 155-162

Bucholz RW, Carlton A, Holmess RE 1987: Hydroxyapatite and tricalcium phosphate bone graft substitutes. Orthop Clin North Am 18: 323-334

Burkus JK, Kornet MF, Dickman CA, Zdeblick TA 2002: Anterior lumbar interbody fusion using rhBMP-2 with tapered interbody cages. J Spinal Disord Tech 15: 337-349

Cancedda R, Bianchi G, Derubeis A, Quarto R 2003: Cell therapy for bone disease: a review of current status. Stem Cells 21: 610-619

Caplan AI 1991: Mesenchymal stem cells. J Orthop Res 9: 641-650

Caplan AI 2005: Review: mesenchymal stem cells: cell-based reconstructive therapy in orthopedics. Tissue Eng 11:1198-1211

Carter DR, Beaupree GS, Giori NJ, Helms JA 1998: Mechanobiology of skeletal regeneration. Clin Orthop 355: 41-55

Carter K 2003: Grow factors: the wound healing therapy of the future. Br J Community Nurs 8: 15-23

Cook SD, Baffes GC, Wolfe MW, Sampath TK, Rueger DC 1994: Recombinant human bone morphogenetic protein-7 induces healing in a canine long-bone segmental defect model. Clin Orthop 301: 302-312

Devine MJ, Mierisch CM, Jang E, Anderson PC, Balian G 2002: Transplanted bone marrow cells localize to fracture callus in a mouse model. J Orthop Res 20: 1232-1239

Devine SM, Peter S, Martin BJ, Barry F, McIntosh KR 2001: Mesenchymal stem cells: Stealth and suppression. Cancer J 7: 76-82

Dressler MR, Butler DL, Boivin GP 2005: Effects of age on the repair ability of mesenchymal stem cells in rabbit tendon. J Orthop Res 23: 287-293

Drosse I, Volkmer E, Capanna R, De Biase P, Mutschler W, Schieker M 2008: Tissue engineering for bone defect healing: an update on a multi-component approach. Injury 39: 9-20

Edgar CM, Chakravarthy V, Barnes G, Kakar S, Gerstenfeld LC, Einhorn TA 2007: Autogenous regulation of a network of bone morphogenetic proteins (BMPs) mediates the osteogenic differentiation in murine marrow stromal cells. Bone 40: 1389-1398

Einhorn TA 1998: The cell and molecular biology of fracture healing. Clin Orthopaed Rel Res 355: 7-21

El-Ghannam A 2005: Bone reconstruction: from bioceramics to tissue engineering. Expert Rev Med Devices 2: 87-101

Fleming JEJ, Cornell CN, Muschler GF 2000: Bone cells and matrices in orthopedic tissue engineering. Orthop Clin North Am 31: 357-374

Friedlaender GE, Perry CR, Cole JD, Cook SD, Cizrny G, Muschler GF, Zych GA, Calhoun JH, LaForte AJ,Yin S 2001: Osteogenic protein-1 (bone morphogenetic protein-7) in the treatment of tibial nonunions. J Bone Joint Surg Am 83: 151-158

Gál P, Nečas A, Plánka L, Kecová H, Křen L, Krupa P, Hlučilová J, Usvald D 2007: Chondrocytic potential of allogenic mesenchymal stem cells transplanted without immunosuppression to regenerate physeal defect in rabbits. Acta Vet Brno 76: 253-263

Gao T, Lindholm TS, Marttinen A, Urist MR 1996: Composites of bone morphogenetic protein (BMP) and Type IV collagen, coral-derived coral hydroxyapatite, and tricalcium phosphate ceramics. Int Orthop 20: $321-325$

Heino TJ, Hentunen TA 2008: Differentiation of osteoblasts and osteocytes from mesenchymal stem cells. Curr Stem Cell Res Ther 3: 131-145

Hoemann CD, Hurtig M, Rossomacha E, Sun J, Chevrier A, Shive MS, Buschmann MD 2005: Chitosan-glycerol phosphate/blood implants improve hyaline cartilage repair in ovine microfracture defects. J Bone Joint Surg (American volume) 87: 2671-2296

Horisaka Y, Okamoto Y, Matsumoto N, Yoshimura Y, Kawada J, Yamashita K, Takagi T 1991: Subperiosteal implantation of bone morphogenetic protein adsorbed to hydroxyapatite. Clin Orthop 268: 303-312

Hotz G, Herr G 1994: Bone substitute with osteoinductive biomaterials - current and future clinical applications. Int J Oral Maxillofac Surg 23: 413-417

Hutmacher DW 2000: Scaffolds in tissue engineering bone and cartilage. Biomaterials 21: 2529-2543

Chen F, Hui JHP, Chan WK, Lee EH 2003: Cultured mesenchymal stem cell transfers in the treatment of partial growth arrest. J Pediatr Orthop 23: 425-429 
Ishaug SL, Crane GM, Miller MJ, Yasko AW, Yaszemski MJ, Mikos AG 1997: Bone formation by threedimensional stromal osteoblast culture in biodegradable polymer scaffolds. J Biomed Mater Res 36: 17-28

Jaiswal N, Haynesworth SE, Caplan AI, Bruder SP 1997: Osteogenic differentation of purified, culture-expanded human mesenchymal stem cells in vitro. J Cell Biochem 64: 295-312

Jančář J, Slovíková A, Amler E, Krupa P, Planka L 2007: Mechanical response of porous scaffolds for cartilage engineering. Phys Res 56: 17-25

Johnson AL 2007: Fundamentals of Orthopedic Surgery and Fracture Management. In: Fossum TW: Small animal Surgery. $3^{\text {th }}$ ed, Mosby, St. Louis, pp. 930-1014

Johnson EE, Urist MR 1998: One-stage lengthening of femoral nonunion augmented with human bone morphogenetic protein. Clin Orthop 347:105-116

Joshi A, Kostakis GC 2004: An investigation of post-operative morbidity following iliac crest graft harvesting. Br Dent J 196: 167-171

Kadiyala S, Jaiswal N, Bruder SP 1997: Culture-expanded, bone marrow-derived mesenchymal stem cells can regenerate a critical-sized segmental bone defect. Tissue Eng 3: 173-185

Kim J, Kim IS, Cho TH, Lee KB, Hwang SJ, Tae G, Noh I, Lee SH, Park Y, Sun K 2007: Bone regeneration using hyaluronic acid-based hydrogel with bone morphogenic protein-2 and human mesenchymal stem cells. Biomaterials 28: 1830-1837

Kirker-Head C, Karageorgiou V, Hofmann S, Fajardo R, Betz O, Krampera M, Pizzolo G, Aprili G, Franchini M 2006: Mesenchymal stem cells for bone, cartilage, tendon and skeletal muscle repair. Bone 39: 678-683

Kraus KH, Kadiyala S, Wotton H, Kurth A, Shea M, Hannan M, Hayes WC, Kirker-Head CA, Bruder S 1999: Critically sized osteo-periosteal femoral defects: a dog model. J Invest Surg 12: 115-124

Kraus KH, Kirker-Head CA 2006: Mesenchymal Stem Cells and bone regenaration. Vet Surg 35: 232-242

Kuznetsov SA, Mankani MH, Gronthos S, Satomura K, Bianco P, Robey PG 2001: Circulating skeletal stem cells. J Cell Biol 153: 1133-1140

Lee EH, Hui HP 2006: The potential of stem cells in orthopaedic surgery. J Bone Joint Surg (British volume) 88: 841-850

Lee JY, Choo JE, Choi YS, Park JB, Min DS, Lee SJ, Rytu HK, Jo IH, Chung CP, Park YJ 2007: Assembly of collagen-binding peptide with collagen as a bioactive scaffold for osteogenesis in vitro and in vivo. Biomaterials 28: $4257-4267$

Li RH, Wozney JM 2001: Delivering on the promise of bone morphogenetic proteins. Trends Biotechnol 19: $255-265$

Marcacci M, Kon E, Zaffagnini S, Giardino R, Rocca M, Corsi A, Benvenuti A, Bianco P, Quarto R, Martin I, Muraglia A, Cancedda R 1999: Reconstruction of extensive long-bone defects in sheep using porous hydroxyapatite sponges. Calcif Tissue Int 64: 83-90

Marie PJ, Fromigue O 2006: Osteogenic differentiation of human marrow-derived mesenchymal stem cells. Regen Med 1: $539-548$

Marx RE 2004: Platelet-rich plasma: evidence to support its use. J Oral Maxillofac Surg 62: 489-496

Meinel L, Betz O, Fajardo R, Hofmann S, Nazarian A, Cory E, Hilbe M, McCool J, Langer R, Vunjak-Novakovic G, Merkle HP, Rechenberg B, Kaplan DL, Kirker-Head C 2006: Silk based biomaterials to heal crirical sized femur defects. Bone 39: 922-931

Merkle HP, Hilbe M, von Rechenberg B, McCool J, Abrahamsen L, Nazarian A, Cory E, Curtis M, Kaplan D, Meinel L 2007: BMP-silk composite matrices heal critically sized femoral defects. Bone 41: 247-255

Nečas A, Plánka L, Srnec R, Raušer P, Urbanová L, Lorenzová J, Crha M, Jančář J, Gál P 2008: Use of biomaterials and stem cells in the treatment of articular cartilage, meniscal, physeal, bone, ligamentous and tendineous defects. Acta Vet Brno 77: 277-284

Neuttelman CR, Tripodi MC, Anseth KS 2006: Dexamethasone-functionalized gels induce osteogenic differentiation of encapsulated hMSCs. J Biomed Mater Res 76: 183-195

Noel D, Djouad F, Jorgense C 2002: Regenerative medicine through mesenchymal stem cells for bone and cartilage repair. Curr Opin Investig Druha 3: 1000-1004

Oe K, Miwa M, Sakai Y, Lee SY, Kuroda R, Kurosaka M 2007: An in vitro study demonstrating that haematomas found at the site of human fractures contain progenitor cells with multilineage capacity. J Bone Joint Surg (British volume) 89: 133-138

Oest ME, Dupot KM, Kong HJ, Money DJ, Guldberg RE 2007: Quantitative assessment of scaffold and growth factor-mediated repair of critically sized bone defects. J Orthop Res 25: 941-950

Pittenger MF, Mackay AM, Beck SC, Jaiswal RK, Douglas R, Mosca JD, Moorman MA, Simonetti DW, Craig S, Marshak DR 1999: Multilineage potential of adult human mesenchymal stem cells. Science 284: 143-147

Plánka L, Nečas A, Gál P, Kecová H, Filová E, Křen L, Krupa P 2007: Prevention of bone bridge formation using transplantation of the autogenous mesenchymal stem cells to physeal defects: An experimental study in rabbits. Acta Vet Brno 76: 257-266

Pluhar GE 2004: Orthopedic application of mesenchymal stem cells. In: Proceedings of the ACVS Veterinary Symposium, October 6.-9. 2004, Denver, Colorado, USA, pp. 326-328

Porada CD, Zanjani ED, Almeida-Porad G 2006: Adult mesenchymal stem cells: a pluripotent population with multiple applications. Curr Stem Cell Res Ther 1: 365-369 
Prockop DJ 1997: Marrow stromal cells as stem cells for non-hematopoietic tissues. Science 276: 71-74

Reddi AH 2000: Morphogenesis and tissue engineering of bone and cartilage: induction signals, stem cells, and biomimetic biomaterials. Tissue Eng 6: 351-359

Reddi AH 2001: Bone morphogenetic proteins: From basic science to clinical applications. J Bone Joint Surg 83: $1-6$

Rosenbaum AJ, Grande DA, Dines JS 2008: The use of mesenchymal stem cells in tissue engineering: A global assessment. Organogenesis 4: 23-27

Salgado AJ, Oliveira JT, Pedro AJ, Reis RL 2006: Adult stem cells in bone and cartilage tissue engineering. Curr Stem Cell Res Ther 1: 345-364

Shirley D, Marsh D, Jordan G, Mcquaid S, Li G 2005: Systemic recruitment of osteoblastic cells in fracture healing. J Orthop Res 23: 1013-1021

Silber JS, Anderson DG, Daffner SD, Brislin BT, Leland JM, Hilibrand AS, Vaccaro AR, Albert TJ 2003: Donor site morbidity after anterior iliac crest bone harvest for single-level anterior cervical discectomy and fusion. Spine 28: 134-139

Slater BJ, Kwan MD, Gupta DM, Panetta NJ, Longaker MT 2008: Mesenchymal cells for skeletal tissue engineering. Expert Opin Biol Ther 8: 885-893

Smith RKW 2006: Mesenchymal stem cells - theory and application. In: Proceedings of the 15th Annual Scientific Meeting, June 29 - July 1, Sevilla, Spain, pp. 207-210

Srouji S, Livne E 2005: Bone marrow stem cells and biological scaffold for bone repair in aging and disease. Mech Ageing Dev 126: 281-187

Stocum DL 2001: Stem cells in regenerative biology and medicine. Wound Rep Reg 9: 429-442

Vallejo LF, Brokelmann M, Marten S, Trappe S, Cabrera-Crespo J, Hoffmann A, Gross G, Weich HA, Dinas U 2002: Renaturation and purification of bone morphogenetic protein-2 produced as inclusion bodies in highcell-density cultures of recombinant Escherichia coli. J Biotechnol 94:185-194

Viateau V, Guillemin G, Bousson V, Oudina K, Hannouche D, Sedel L, Logeart-Avramoglou D, Petite H 2007 : Long-bone critical-size defects treated with tissue-engineered grafts: a study on sheep. J Orthop Research 22: 741-749

Waese EY, Kandel RA, Stanford WL 2008: Application of stem cells in bone repair. Skeletal Radiol 37: 601-608

Wolff D, Goldberg VM, Stevenson S 1994: Histomorphometric analysis of the repair of a segmental diaphyseal defect with ceramic and titanium fibermetal implants: Effects of bone marrow. J Orthop Res 12: 439-446

Yamamoto M, Tabata Y, Ikada Y 1998: Ectopic bone formation induced by biodegradable hydrogels incorporating bone morphogenetic protein. J Biomater Sci Polym 9: 439-458

Yoo JU, Johnstone B 1998: The role of osteochondral progenitor cells in fracture repair. Clin Orthop 335: 73-81

Zaidi N, Nixon AJ 2007: Stem cell therapy in bone repair and regeneration. Ann NY Acad Sci 1117: 62-72 
Plate VIII

Crha M. et al.: Mesenchymal ... pp. 635-642

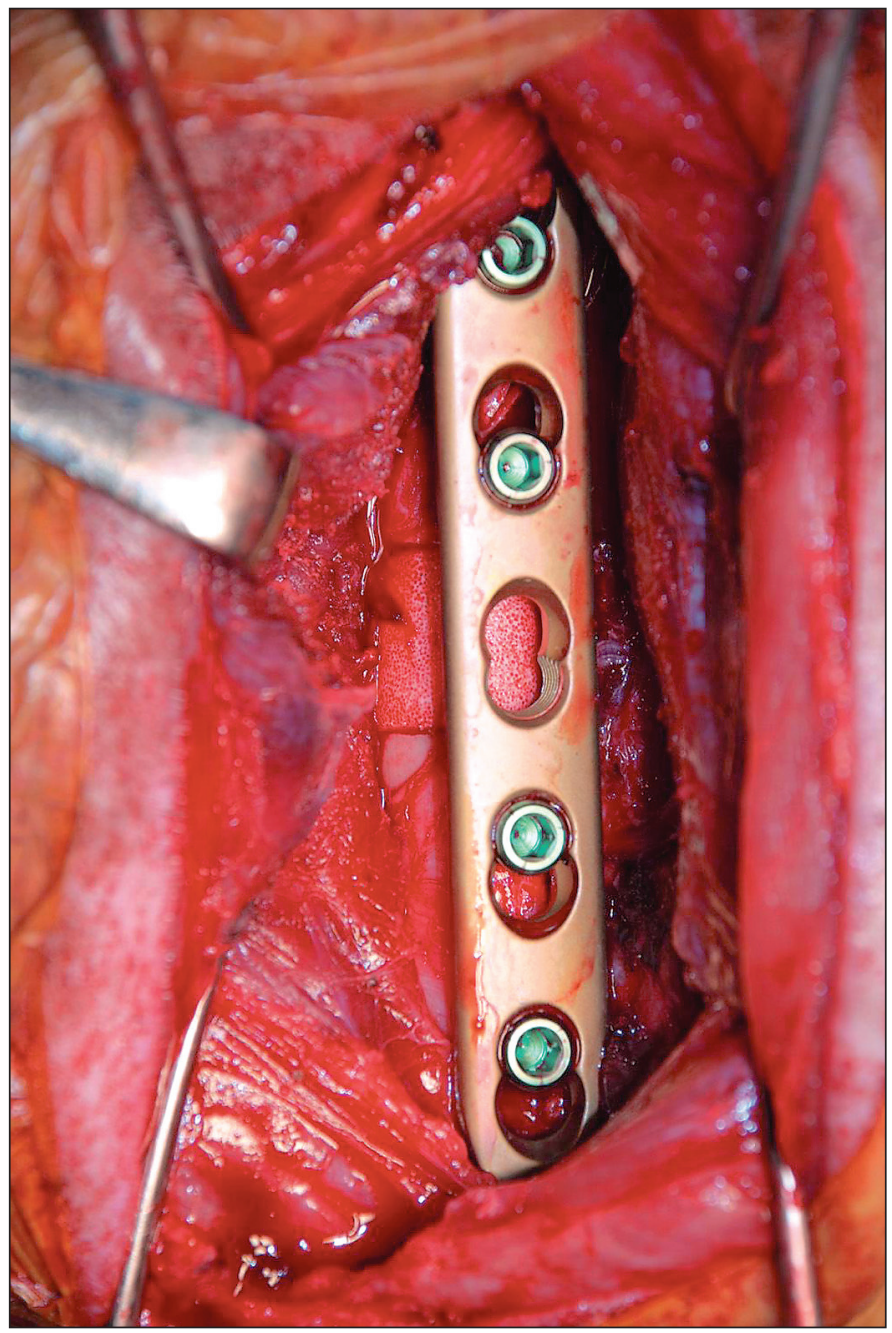

Fig. 1. Transplantation of biocompatible scaffold seeded with MSCs into segmental femoral defect fixed with LCP plate in a miniature pig 
Plate IX

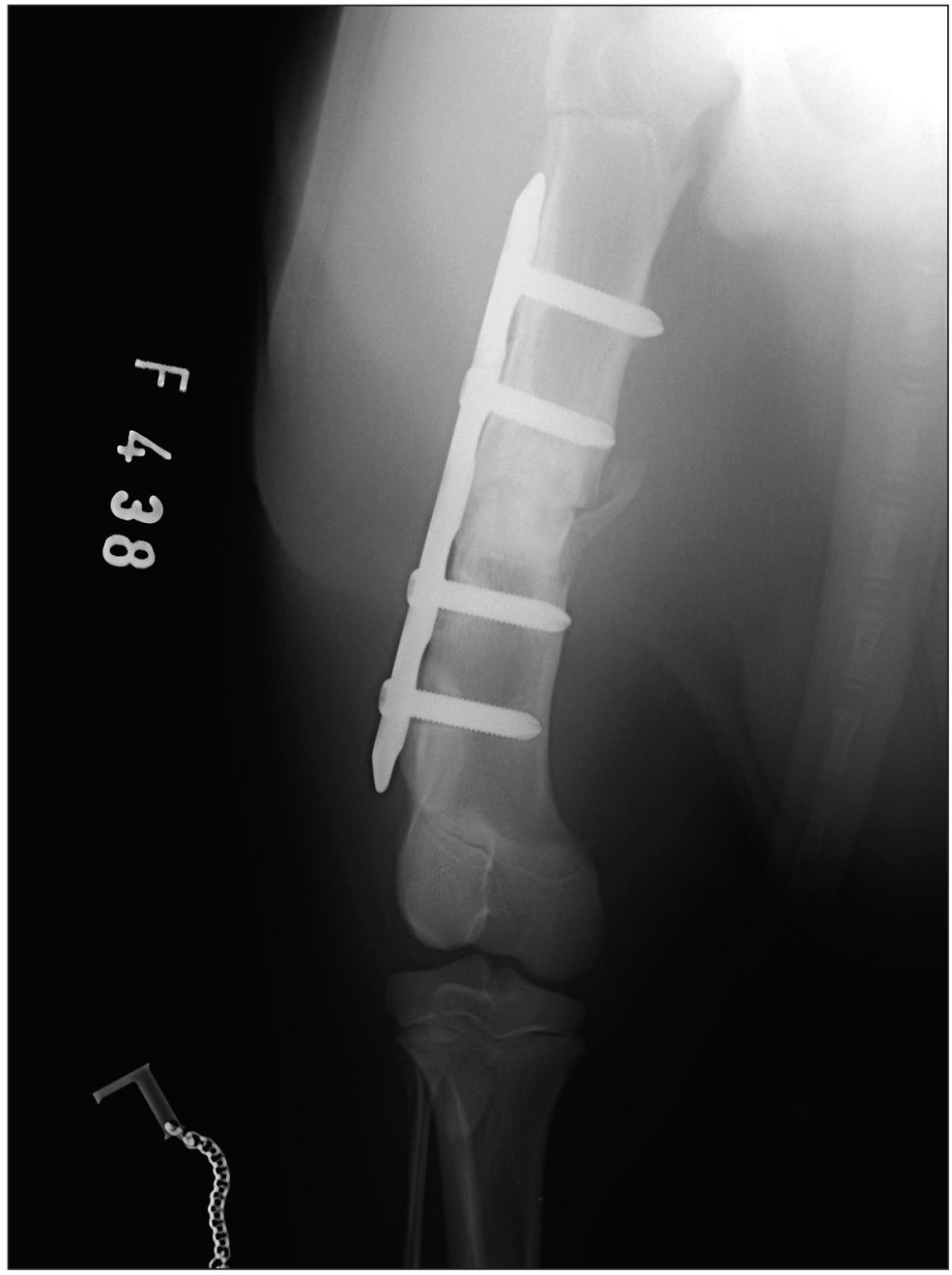

Fig. 2. Radiographic evaluation of the femur (caudocranial view) sixteen weeks after transplantation of the scaffold seeded with MSCs in the same miniature pig 
Plate X

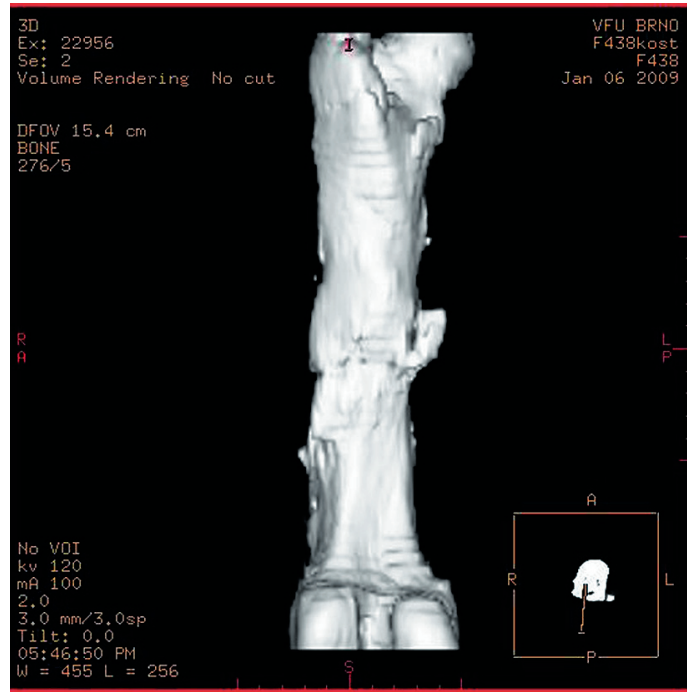

Fig. 3. Healed femoral defect on 3D computed tomography (caudocranial view) sixteen weeks after transplantation in the same miniature pig (LCP plate removed) 